\title{
KONWENCJA DOTYCZĄCA STATUSU UCHODŹCÓW A PRAKTYKA TURECKA. PROBLEM PRZYBYSZÓW ZZA WSCHODNIEJ GRANICY
}

Jedną z najbardziej doniosłych konsekwencji trwających od końca 2010 r. zamieszek społecznych i konfliktów zbrojnych zwanych zbiorczo arabską wiosną jest obserwowany w regionie wydarzeń wzrost intensywności procesów migracyjnych. W największym stopniu zjawisko to dotyczy Syryjskiej Republiki Arabskiej, w której protesty i wystąpienia skierowane przeciwko władzy prezydenta Baššāra al-'Asada ${ }^{1}$ przerodziły się w wojnę domową, w której przeciwko siłom rządowym występuje Armia Wolnej Syrii, aspirująca do reprezentowania głęboko podzielonej i wewnętrznie zróżnicowanej opozycji. Naturalną konsekwencją działań zbrojnych, obejmujących swym zasięgiem całe terytorium państwa, są nasilające się migracje ludności cywilnej, której bezpieczeństwo jest permanentnie zagrożone od wiosny 2011 r., kiedy to wybuchły pierwsze zamieszki. Proces ten cechuje się szczególną intensywnością w północnych obszarach Syrii, których mieszkańcy masowo podejmują decyzję o ucieczce do Turcji, której władze całkowicie przeorientowały swą politykę wobec syryjskiej wojny domowej. O ile jeszcze jesienią 2011 r. premier Republiki Turcji Recep Tayyip Erdoğan jednoznacznie opowiadał sie po stronie legalnej władzy Baššāra al-'Asada („Vatan”, 2011) o tyle z czasem, pod wpływem różnorodnych czynników, odciął się od niej i ostatecznie opowiedział po stronie sił opozycyjnych. W efekcie, lawinowo wzrosła liczba Syryjczyków poszukujących schronienia na terytorium Turcji - jak podaje turecki Departament Zarządzania Kryzysowego, w lutym 2014 r. liczba ta przekroczyła 700 tysięcy, z czego około 220 tysięcy znalazła schronienie w przygranicznych obozach dla uchodźców (Afet, 2014). Coraz bardziej obciążony finansowo i organizacyjnie rząd turecki, ustami ministra do spraw europejskich apeluje do Unii Europejskiej o przyjęcie części uciekinierów z Syrii i odciążenie Turcji („Die Welt”, 2012), strona unijna wskazuje jednak na inny problem - nierespektowanie przez Turcję standardów prawa międzynarodowego istotnych dla ochrony praw uchodźców. Celem niniejszej analizy jest ukazanie specyfiki tureckiej polityki wobec uciekinierów w zależności od państwa ich pochodzenia, w kontekście norm prawa międzynarodowego regulujących kwestię uchodźstwa.

\footnotetext{
${ }^{1}$ W zapisach nazw arabskich przejęto zasady transliteracji ISO (Międzynarodowej Organizacji Normalizacyjnej).
} 


\section{PRAWNOMIĘDZYNARODOWE PODSTAWY OCHRONY UCHODŹCÓW}

Jak wskazano w preambule konwencji, przyjęcie dokumentu było poniekąd kontynuacją realizacji celów, jakie przyświecały im podczas formułowania treści Karty Narodów Zjednoczonych oraz Powszechnej Deklaracji Praw Człowieka, stanowiących podwaliny współczesnego systemu ochrony praw człowieka. Sformułowanie i przyjęcie aktu było kolejnym etapem budowy tego systemu, będącym przede wszystkim odpowiedzią społeczności międzynarodowej na wzmożone zjawiska migracji, związane z zakończeniem II wojny światowej i kształtowaniem się powojennego ładu. Innymi słowy, ambicją umawiających się państw była budowa narzędzia, które umożliwiałoby stworzenie powszechnego i jednolitego systemu ochrony praw uchodźców tak, by osoby otrzymujące ów status miały zapewnione te same gwarancje we wszystkich państwach, które zdecydują się do konwencji przystapić. Warunkiem sine qua non ustalenia wspólnej formuły było przede wszystkim osiagnięcie kompromisu w kwestii definicji pojęcia ,uchodźca”, tak, by budziło ono jak najmniej kontrowersji, a tym samym pozwoliło jak największej liczbie państw na ratyfikowanie dokumentu. I tak, zgodnie z artykułem 1 dokumentu, uchodźcą jest osoba, która „w rezultacie zdarzeń, jakie nastapiły przed dniem 1 stycznia 1951 r., oraz na skutek uzasadnionej obawy przed prześladowaniami z powodu swojej rasy, religii, narodowości, przynależności do określonej grupy społecznej lub z powodu przekonań politycznych, przebywa poza granicami państwa, którego jest obywatelem i nie może lub nie chce z powodu tych obaw korzystać z ochrony tego państwa, albo która nie ma żadnego obywatelstwa i znajdując się na skutek podobnych zdarzeń poza państwem swojego dawnego stałego zamieszkania, nie może lub nie chce z powodu tych obaw powrócić do tego państwa" (Konwencja, 1951: art. 1). Jednocześnie, w dalszej części tego samego artykułu postanowione zostaje, że przez padające w ustępie A stwierdzenie o „wydarzeniach mających miejsce przed dniem 1 stycznia 1951 roku, należy rozumieć (a) „wydarzenia, które nastapiły w Europie przed 1 stycznia 1951 r.” lub (b) „wydarzenia, które miały miejsce w Europie lub gdziekolwiek indziej przed dniem 1 stycznia 1951 r.; każde z Umawiających się Państw, w momencie podpisywania, ratyfikacji lub przystapienia złoży oświadczenie, które z tych określeń zamierza stosować, realizując zobowiązania przyjęte przez siebie na podstawie niniejszej Konwencji” (ibidem). W ten sposób stworzona została prawna możliwość skorzystania z wyłączeń w stosowaniu jej przepisów w oparciu o kryterium geograficzne - albo w stosunku do osób będących ofiarami wydarzeń, do jakich doszło przed 1 stycznia $1951 \mathrm{r}$. tylko w obrębie kontynentu europejskiego, albo w stosunku do osób, które stały się ofiarami takich zajść, mających miejsce gdziekolwiek na świecie. Turcja, jako jedno z czterech państw, obok Monako, Madagaskaru i Kongo, zdecydowała się na zastosowanie tego kryterium, czego przyczyny i doniosłe konsekwencje zaprezentowane zostaną w dalszej części niniejszej analizy.

W treści dokumentu enumeratywnie wymienione zostały osoby, którym prawo do skorzystania ze statusu nie przysługuje, w tym między innymi te, co do których istnieje uzasadnione podejrzenie, iż dokonały zbrodni przeciwko pokojowi, zbrodni wojennej lub zbrodni przeciwko ludzkości w rozumieniu odpowiednich aktów międzynarodowych, dokonały poważnej zbrodni o charakterze niepolitycznym poza państwem, przez które zostały przyjęte czy są winne czynów sprzecznych z celami i zasadami Na- 
rodów Zjednoczonych (art. 1 ust. F). Wszystkim osobom, nie objętym wyłączeniami określonymi w ustępach C, D, E i F artykułu 1 konwencji, dokument zagwarantował możliwość wystąpienia do władz państwa przyjmującego o nadanie statusu uchodźcy, z którym wiąże się cały szereg gwarancji i przywilejów, ale również obowiązków. Przede wszystkim, osoba, której nadano taki status, obowiązana jest do tego, by przestrzegać wszystkich praw i przepisów państwa przyjmującego, a także środków podjętych w celu utrzymania porządku publicznego (art. 2). Jednocześnie, zakazana została jakakolwiek dyskryminacja uchodźców ze względu na ich rasę, religię czy państwo pochodzenia (art. 3), a państwa-strony zobowiązały się do zapewnienia uchodźcom wolności praktyk religijnych i religijnego wychowania dzieci (art. 4).

Status osobowy każdego uchodźcy określa prawo państwa, na którego terytorium znajduje się jego stałe miejsce zamieszkania, a w przypadku braku takiego miejsca, prawo państwa, w którym aktualnie on przebywa. Jednocześnie, ważność zachowują wszystkie prawa związane ze statusem osobowym, jakie uchodźca nabył wcześniej, w tym przede wszystkim prawa związane z małżeństwem (art. 12). Ponadto, osobom legitymującym się tym statusem przysługują takie same prawa w zakresie nabywania ruchomości i nieruchomości, co wszystkim cudzoziemcom (art. 13), w zakresie zaś własności intelektualnej i przemysłowej podlegają takim samym prawom, jak obywatele państwa przyjmującego (art. 14). Konwencja przyznała im również tak samo korzystne, jak innym obcokrajowcom, prawa w zakresie wolności zrzeszania się i tworzenia stowarzyszeń o charakterze niepolitycznym i niezarobkowym (art. 15). Na zasadzie równości z obywatelami państwa, na terytorium którego uchodźcy przebywają korzystają oni z prawa dostępu do sądów, a każdy z nich ma prawo swobodnego dostępu do sądów na terytoriach wszystkich państw-stron (art. 16). Ponadto, konwencja przyznała osobom, które uzyskały status uchodźcy, prawo do podejmowania pracy zarobkowej, na warunkach przynajmniej tak samo korzystnych, jak te, które dotyczą wszystkich innych obcokrajowców (art. 17), a podobny przepis dotyczy również uchodźców zakładających działalność gospodarczą (art. 18). Państwa, które ratyfikowały konwencję, zobowiązały się również do uznania dyplomów, którymi legitymują się uchodźcy, chcący na terytorium państwa przyjmującego wykonywać wolny zawód (art. 19). Istotnym uzupełnieniem dla tego zapisu, jest zobowiązanie się państw stron do zapewnienia uchodźcom takich samych praw, jak w zakresie dostępu do szkolnictwa podstawowego mają obywatele danego państwa, oraz jak najlepszych zasad w przedmiocie dostępu do szkolnictwa innego niż podstawowe, w tym uznawalności świadectw i stopni naukowych, zwolnień z czesnego oraz przyznawania stypendiów (art. 22). Równie daleko idą zobowiązania państw stron w zakresie świadczeń socjalnych, jakie zapewnione mają być uchodźcom - w zakresie korzystania $\mathrm{z}$ opieki społecznej mają oni być traktowani identycznie z obywatelami danego państwa (art. 23). Za tym zaś idzie wiele praw i przywilejów w zakresie ubezpieczeń społecznych i praw pracowniczych, jakie zasadniczo nie odbiegają od tych, które przysługują obywatelom państwa przyjmującego (art. 24). Konwencja szeroko odnosi się także do kwestii środków administracyjnych, przysługujących uchodźcom, w tym prawa wyboru miejsca zamieszkania $\mathrm{w}$ granicach terytorium państwa przyjmującego i wolności poruszania się po nim (art. 26), prawa do otrzymania dokumentu tożsamości (art. 27) oraz tzw. genewskiego dokumentu podróży, niezbędnego do poruszania się poza jego granicami (art. 28). 
Szczegółowo uregulowane są także kwestie związane z nielegalnym pobytem uchodźców na terytorium państwa przyjmującego. Państwa-strony podjęły zobowiązanie, zgodnie z którym na uchodźców przybywających nielegalnie bezpośrednio z terytorium państwa, na którym ich życiu lub wolności zagrażało niebezpieczeństwo, nie będą nakładane kary za nielegalny wjazd i pobyt, jeśli niezwłocznie zwrócą się do odpowiednich władz, przedstawiając im wiarygodną przyczynę swojego przybycia (art. 31). Ponadto, żadne z państw-stron nie może dopuścić się wydalenia uchodźcy z powodów innych niż bezpieczeństwo państwa lub porządek publiczny, a ewentualna decyzja o takim wydaleniu musi zapaść w oparciu o procedurę przewidzianą przepisami prawa (art. 32). Wreszcie, w artykule 33 konwencji sformułowana została zasada non-refoulement, która zakazuje wydalenia bądź zawrócenia uchodźcy na terytorium, na którym ze względu na jego rasę, religię, obywatelstwo, przynależność do określonej grupy społecznej lub poglądy polityczne, jego życiu lub wolności zagrażałoby niebezpieczeństwo. Zasada ta przez wielu ekspertów uznana jest za normę ius cogens, bezwzględnie obowiązującą normę prawa międzynarodowego, której obowiązywanie nie może zostać wolą stron ograniczone lub wyłączone (Konwencja wiedeńska, 1969: art. 53). Bardzo istotnym jest również zapis artykułu 38, zgodnie z którym każdy spór, jaki wyniknie pomiędzy stronami konwencji, dotyczący jej stosowania lub interpretowania, będzie mógł decyzją jednej z jego stron zostać skierowany do Międzynarodowego Trybunału Sprawiedliwości ${ }^{2}$.

To właśnie istnienie tego zapisu stało się jedną z przyczyn, dla których podjęto decyzję o sporządzeniu protokołu dodatkowego do tej umowy międzynarodowej, niebędącego jednak jej rewizją w rozumieniu art. 45, a odrębnym aktem prawnym, do którego państwo może przystąpić, nie będąc jednocześnie stroną samej konwencji. Drugim istotnym powodem, dla którego uznano jego sporządzenie za wskazane, było istnienie zapisanych w artykule 1 konwencji kryteriów czasowego i geograficznego, o których wspomniano powyżej. Zmieniająca się sytuacja geopolityczna na świecie i wynikająca z tych zmian coraz mniejsza przystawalność owych kryteriów do rzeczywistości międzynarodowej, skłoniły państwa strony do ponownego pochylenia się nad problemem uciekinierów z państw ich obywatelstwa i przeformułowaniem definicji pojęcia „uchodźca”. Prace nad protokołem rozpoczęły się w 1965 roku i trwały kolejne dwa lata, a ich efektem stała się umowa, której strony zobowiązały się do stosowania wobec uchodźców artykułów 2-34 konwencji oraz rozumienia pojęcia uchodźca tak, jakby w jej pierwszym artykule, zawierającym jego definicję, nie zostało użyte sformułowanie o wydarzeniach, jakie miały miejsce przez 1 stycznia 1951 r. Ponadto, państwa strony zobowiązały się do niestosowania w przedmiocie przyznawania statusu uchodźcy żadnego kryterium geograficznego, choć wprowadzona zostaje możliwość podtrzymania oświadczeń w sprawie geograficznych ograniczeń stosowania konwencji, jakie złożone zostały przez poszczególne państwa w momencie jej podpisywania bądź ratyfikacji (Protokót, 1967: art. 1). Innymi słowy, celem państw przystępujących do Protokołu było stworzenie możliwie najszerszej interpretacji pojęcia 'uchodźca' tak, by status ten mogły zacząc otrzymywać wszystkie osoby, spełniające warunek

2 Wszystkie wymienione przepisy dotyczące statusu uchodźcy pochodzą z Konwencji dotyczqcej statusu uchodźców z $1951 \mathrm{r}$. 
zawarty w pierwszym artykule konwencji, a więc zagrożone prześladowaniami lub obawą przed nimi ze względu na rasę, religię, narodowość, przynależność do określonej grupy społecznej lub poglądy polityczne. Przestać obowiązywać miały cezura czasu i kryterium geograficzne, jednak państwom, które z drugiego z nich skorzystały, pozostawiono możliwość jego podtrzymania.

Katalog państw-stron każdej z umów nie jest jednolity, nie wszystkie rządy zdecydowały się również na pełne dostosowanie do zmian wprowadzonych przez protokół. Według informacji Wysokiego Komisarza Narodów Zjednoczonych do spraw Uchodźców, 1 marca 2014 r., stronami konwencji było 145 państw, zaś protokołu 146, przy czym 143 państwa są stronami obydwu dokumentów. Trzy państwa - Stany Zjednoczone Ameryki, Republika Zielonego Przylądka i Wenezuela, nie godząc się na jurysdykcję Międzynarodowego Trybunału Sprawiedliwości, a jednocześnie dostrzegając potrzebę ochrony praw uchodźców, przystapiły wyłącznie do Protokołu. Z kolei Madagaskar oraz Saint Kitts i Nevis w ogóle odmówiły przystapienia do niego, pozostając jednocześnie stronami konwencji. Trzecią drogę wybrała natomiast Turcja (a także Monako, Madagaskar i Kongo ${ }^{3}$ ), której rząd podjął decyzję o utrzymaniu w mocy deklaracji złożonej zgodnie z ustępem B artykułu 1 konwencji, dającym jej prawo do stosowania w materii przyznawania statusu uchodźcy kryterium geograficznego. W efekcie, Turcja, która ratyfikowała konwencję 30 marca 1962 r., a do protokołu przystapiła 31 lipca 1968 r. (UNHCR, 2014), dopuszcza nadawanie statusu uchodźcy wyłącznie przybyszom z państw europejskich, a wszyscy inni pozbawieni są możliwości jego uzyskania. Przyczyny, dla których kwestię uchodźstwa rozwiązano w ten sposób, oraz jego konsekwencje zostaną ukazane w dalszej części niniejszej analizy.

\section{SPECYFIKA TURECKIEJ POLITYKI WOBEC PROBLEMU UCHODŹSTWA}

Warunkiem sine qua non rzetelnej analizy i zrozumienia sensu tureckiej polityki wobec zjawiska uchodźstwa, jest odniesienie się do jej położenia geopolitycznego i sytuacji w regionie Bliskiego Wschodu w okresie, w którym przyjmowano konwencję i Protokół nowojorski. Lata czterdzieste XX wieku to dla państw tego obszaru przede wszystkim okres niepokojów, związanych z toczącą się w Europie II wojną światową i rywalizacją zaangażowanych w nią sił o wpływy w regionie. Nie było właściwie w otoczeniu Turcji państwa, z którego emigracja w omawianym okresie czasu nie nasiliłaby się w sposób na tyle znaczny, by stanowić dla niej rzeczywisty problem. Pewnymi wyjątkami były jedynie Gruzja i Armenia, w których względną stabilność polityczną zapewniło wcielenie ich do ZSRR, co w połączeniu z małą liczebnością zamieszkujących je narodów spowodowało, że aż do przełomu lat 80. i 90. XX w. problem pochodzących z nich uchodźców właściwie nie istniał. W przypadku Armenii bardzo istotną rolę odgrywała świeża pamięć o wydarzeniach z lat 1915-1916, przez znaczną

3 Monako zdecydowało się na przyjęcie protokołu w 2010 r., wciąż go jednak nie ratyfikowało; Madagaskar odmówił zniesienia kryterium terytorialnego, jednocześnie w ogóle nie przyjmując protokołu. 
część państw świata uznawanych za ludobójstwo na Ormianach, nigdy jednak za takie nieuznane przez Turcję. Sytuacja ta, nasilona dodatkowo po trwającej do 1994 r. wojnie z protureckim Azerbejdżanem, do dziś owocuje tym, że Turcja nie jest kierunkiem potencjalnej emigracji dla poszukujących bardziej dostatniego życia Ormian. Nieco inaczej stało się w przypadku Gruzji, z której po pierwszej wojnie w Osetii Południowej w latach 1991-1992 na terytoria Turcji przybywać zaczęły coraz większe ilości uchodźców, wciąż jednak nie są to grupy, których obecność mogłaby zagrozić tureckiemu porządkowi publicznemu czy bezpieczeństwu państwa. W przeciwieństwie jednak do Gruzji i Armenii, sytuacja wewnętrzna wszystkich innych państw położonych za wschodnimi granicami Turcji, była w czasie, w którym przygotowywano konwencję, dalece niestabilna. Dokonana w połowie 1941 r. brytyjsko-sowiecka inwazja na Iran, mająca na celu obalenie przejawiającego proniemieckie sympatie szacha Rezy Pahlawi’ego, kryzys z 1946 r. i powstanie na granicy turecko-irańskiej niezależnej kurdyjskiej Republiki Machabadzkiej zaowocowały wzrostem liczby Irańczyków szukających schronienia w Turcji. Podobne skutki przyniosły wydarzenia początku lat czterdziestych w Iraku, w którym w reakcji na kapitulację Francji w II wojnie światowej narastać zaczęły nastroje proniemieckie i apele o sojusz z III Rzeszą, w odpowiedzi na co okupację Iraku rozpoczęła armia brytyjska, a brytyjski rząd okupacyjny wypowiedział wojnę państwom Osi. Jeszcze bardziej niestabilnie kształtowała się sytuacja w Syrii, która już w 1948 r. wzięła udział w pierwszej wojnie z Izraelem, a tylko w roku następnym miały miejsce trzy zamachy stanu. Mimo że okres najbardziej wzmożonej emigracji z tych państw na terytoria Turcji miał dopiero nadejść, a tureccy przywódcy polityczni nie mogli się spodziewać wydarzeń, do jakich miało dojść w kolejnych dekadach XX wieku, rząd premiera Adnana Menderesa nie zdecydował się na przyjęcie konwencji bez zastosowania kryterium geograficznego. Decyzję tę potwierdzono w 1968 roku, kiedy rząd Turcji zdecydował o przystappieniu do Protokołu Nowojorskiego, zachwoując przy tym prawo do stosowania kryterium geograficznego. Protokół ów do dziś nie został przez Turcję ratyfikowany. W ten sposób, w polityce, jaką kolejne rządy tureckie prowadzą wobec uciekinierów z innych państw, pojawiła się charakterystyczna dwoistość: o ile sytuację uchodźców z państw europejskich reguluje umowa międzynarodowa, jaką jest Konwencja dotycząca statusu uchodźców, o tyle już położenie prawne przybyszów z państw pozaeuropejskich wynika z aktu prawa wewnętrznego - Ustawy o warunkach pobytu i przemieszczania się obcokrajowców po terytorium Turcji z 15 lipca 1950 r.

Jak wskazano powyżej, konwencyjny status uchodźcy wiąże się z wieloma prawami i przywilejami należnymi osobie, której go nadano, a do których zapewnienia państwa strony zobowiązały się w momencie ratyfikowania konwencji. Dokument, poza kryterium geograficznym, nie przewiduje możliwości wyłączenia tych zobowiązań wobec żadnej grupy, nie tworzy też odrębnych procedur ubiegania się o możliwość skorzystania z któregoś z praw konkretnie, co oznacza, że sam fakt nadania statusu uchodźcy powoduje po stronie państwa, które go przyznało, obowiązek wywiązania się ze wszystkich postanowień konwencji. Świadomy tego rząd Turcji, w obawie przed koniecznością zapewnienia wszystkich tych praw rzeszom przybyszów z targanych niepokojami państw Bliskiego i Środkowego Wschodu, konsekwentnie odmawia rezygnacji z kryterium geograficznego, a sytuacja tych osób jest od przeszło sześćdziesięciu 
lat regulowana przez ten sam dokument - Ustawę o warunkach pobytu i przemieszczania się obcokrajowców po terytorium Turcji. Stanowi ona najważniejszą podstawę prawną wjazdu i pobytu obcokrajowców w tym państwie, zawiera bowiem regulacje dotyczące obowiązku legalizacji pobytu w zależności od charakteru wizyty, który może być turystyczny, biznesowy, związany z działalnością edukacyjną, sportową bądź kulturalną. Jednocześnie, ustawodawca tylko w jednym miejscu odnosi się do okoliczności, jakie spowodowały przybycie obcokrajowca do Turcji, stanowiąc, że „Obcokrajowcy szukający w Turcji schronienia z powodów politycznych, mogą osiedlić się tylko w miejscach zaakceptowanych przez Ministerstwo Spraw Wewnętrznych" (Yabancılarin, 1950: art. 17). Cytowany artykuł zatytułowany jest Uchodźcy polityczni (tur. siyasi mülteciler) i do momentu ratyfikowania przez Turcję konwencji, stanowił jedyne istniejące na gruncie tureckiego wewnątrzkrajowego porządku prawnego odniesienie do problemu uchodźstwa. Status tych osób, ani przysługujące im prawa, nie zostały jednak w żaden sposób wyodrębnione, co sytuuje je w pozycji niczym nie różniącej się od położenia osób przybyłych do Turcji w celach turystycznych, zarobkowych czy innych, wymienionych powyżej. Co więcej, ustawodawca, stanowiąc o konieczności uzyskania zgody Ministerstwa Spraw Wewnętrznych na osiedlenie się w danym miejscu, dodatkowo ograniczył prawa uchodźców w stosunku do innych obcokrajowców, którzy zgodę na pobyt uzyskują we właściwym terytorialnie komisariacie policji (art. 12). Na uchodźców, którzy nie dopełnią obowiązku uzyskania odpowiedniej zgody, aż do połowy roku 2012 mogła zostać nałożona kara pozbawienia wolności w wymiarze od 1 miesiąca do 2 lat. Zapis ten zmieniony został dopiero mocą ustawy z 2 lipca 2012 r., która sankcję tę zastapiła grzywną w wysokości od 500 do 3000 lir tureckich. Zarówno stara, jak i nowa wersja tego przepisu, stoi w sprzeczności z konwencyjnym zobowiązaniem się państw stron do niekarania uchodźców za nielegalny pobyt lub przekroczenie granicy w sytuacji, gdy przybywają oni bezpośrednio $\mathrm{z}$ terytorium, na którym ich życie lub wolność były zagrożone. Podobnie jest w przypadku zapisu, zgodnie z którym „Osoby przebywające w Turcji, które zagrażają porządkowi publicznemu, stabilności politycznej i ładowi administracyjnemu mogą zostać poproszone o opuszczenie jej terytorium w określonym przedziale czasowym. Jeśli tego nie uczynią, po jego upływie mogą zostać wydalone" (ibidem: art. 19). Możliwa dowolność interpretacji przytaczanego artykułu dawała władzom tureckim podstawę do wydalenia z terytorium Turcji każdej osoby, która została przez nie uznana za zagrożenie dla interesów państwa. To zaś, w połączeniu z brakiem zasady non-refoulement, powodowało, że wydalony mógł być każdy, bez względu na to, co grozić by mu miało po opuszczeniu terytorium Turcji.

Pozytywną zmianę tej sytuacji przyniosło ratyfikowanie przez Turcję konwencji dotyczącej Statusu Uchodźców i zobowiązanie się tym samym do przestrzegania jej postanowień w przedmiocie niewydalania uchodźców na terytoria, na których ich życiu lub wolności może zagrażać niebezpieczeństwo. Jednocześnie fakt, iż zasada non-refoulement nie miała od początku charakteru normy ius cogens powodował, że Turcja zobowiązana była do jej respektowania w stosunku do tych tylko osób, którym władze zdecydowały się przyznać status uchodźcy. Innymi słowy, przyjęte w momencie ratyfikacji konwencji kryterium geograficzne zwalniało Turcję ze stosowania tej zasady wobec osób, które statusu tego nie mogły uzyskać, ponieważ pochodzily z państw 
pozaeuropejskich. Ewolucja prawa międzynarodowego i coraz silniejsza tendencja do traktowania zasady non-refoulement jako ius cogens ${ }^{4}$ ponownie jednak postawily sposób postępowania Turcji w tej materii pod znakiem zapytania, skoro bowiem współcześnie non-refoulement ma mieć charakter normy bezwzględnie obowiązującej, nie może mieć miejsca wybiórcze jej stosowanie. W efekcie, zasada zakazu wydalania uchodźców zawarta w artykule 33 konwencji przestała mieć charakter wyłącznie normy konwencyjnej, której państwa-strony muszą przestrzegać w zakresie takim, w jakim przystapiły do umowy. Wbrew jednak temu, jak wskazuje w swym raporcie okresowym Amnesty International, nielegalne deportacje z Turcji, zwłaszcza do Iraku i Iranu wciąż mają miejsce i odbywają się z pominięciem wszelkich procedur (Opuszczeni, 2009). Procederowi temu sprzyja utrzymywanie przez Turcję kryterium geograficznego, ono bowiem powoduje, że zjawiska migracji na wschodnich jej granicach właściwie nie podlegają kontroli międzynarodowej, w tym przede wszystkim jurysdykcji Międzynarodowego Trybunału Sprawiedliwości, o której mówi artykuł 38 konwencji.

Usankcjonowaniem takiego stanu rzeczy na gruncie wewnątrzkrajowego porządku prawnego Turcji jest Rozporzadzenie w sprawie zasad i procedur dotyczacych osób poszukujacych w Turcji schronienia, badź ubiegajacych się o prawo pobytu na jej terytorium $w$ celu przemieszczenia się do państwa trzeciego, badź przekraczajacych jej granice w ramach uchodźstwa zbiorowego, i innych możliwych ruchów ludności. Przyjęty w 1994 r. dokument ostatecznie utrwalił dychotomiczny podział osób przybywających na terytorium Republiki Turcji ze względu na grożące im niebezpieczeństwo, na uchodźców i nie-uchodźców, nadając tym ostatnim status ,poszukujących schronienia". Artykuł 3 rozporządzenia wyraźnie definiuje oba terminy, za uchodźcę (tur. mülteci) uznając osobę, która „na skutek wydarzeń, jakie miały miejsce w Europie, w wyniku uzasadnionej obawy przed prześladowaniami z powodu swojej rasy, religii, narodowości, przynależności do określonej grupy społecznej lub z powodu przekonań politycznych, przebywa poza granicami państwa, którego jest obywatelem i nie może lub nie chce z powodu tych obaw korzystać z ochrony tego państwa, albo która nie ma żadnego obywatelstwa i znajdując się na skutek podobnych zdarzeń poza państwem swojego dawnego stałego zamieszkania, nie może lub nie chce $\mathrm{z}$ powodu tych obaw powrócić do tego państwa" (Türkiye’ye Illtica Eden, 1994: art. 3). Zawarta w tym samym artykule definicja 'poszukującego schronienia' (tur. sığınmacı) brzmi identycznie, z tą jednak różnicą że brak na jej początku sformułowania o „wydarzeniach, jakie miały miejsce w Europie". Jak wspomniano powyżej, w jedynym miejscu ustawy o warunkach pobytu i przemieszczania się obcokrajowców po terytorium Turcji, w którym ustawodawca odnosi się do kwestii uchodźstwa politycznego, użyte zostało tureckie słowo mülteci, oznaczające tyle, co „uchodźca”. W momencie uchwalania ustawy, kiedy Turcja nie była jeszcze stroną konwencji dotyczącej statusu uchodźców, zastosowanie tego określenia nie rodziło problemów, nie wchodziło bowiem w kolizję z prawnomiędzynarodowym znaczeniem tego pojęcia. Jednakże od momentu ratyfikowania kon-

4 O ewolucji tej pisze między innymi Jean Allain w artykule pod tytułem Insisting on the Jus Cogens Nature of Non-Refoulement, zamieszczonym w pracy zbiorowej The Refugee Convention at Fifty: A view from Forced Migration Studies, (red.) J. van Selm, wydanej w 2001 roku przez wydawnictwo Lexington Books z Nowego Jorku na okoliczność pięćdziesiątej rocznicy podpisania konwencji. 
wencji, w którym Turcja zobowiązała się do rozpoznawania tego statusu i związanych z nim praw i przywilejów, wciąż obecne w ustawie określenie mülteci-uchodźca, rodzić zaczęło wątpliwości. Rozporządzenie z 1994 r. miało położyć kres tym definicyjnym rozważaniom i porządkować zasady oraz procedury obowiązujące osoby, które przybywają do Turcji z państw pozaeuropejskich. Z jednej więc strony sam fakt pojawienia się takiego aktu stanowił krok w stronę usystematyzowania kwestii ,uchodźstwa" i „poszukiwania schronienia”, z drugiej jednak niektóre zawarte w nim przepisy budzić mogą watpliwości. Wśród nich najbardziej kontrowersyjnym jest zapis, zgodnie z którym „Osoby przybywające do Turcji w poszukiwaniu schronienia na jej terytorium, bądź w celu przemieszczenia się do państw trzecich i schronienia się na ich terytorium, zobowiązane są do tego, by w ciągu pięciu dni zgłosić się do właściwego terytorialnie urzędu gubernatora, jeśli przekroczyły granicę legalnie, lub do urzędu imigracyjnego, znajdującego się w miejscu, w którym ją przekroczyły, jeśli doszło do tego nielegalnie" (ibidem: art. 29). Zastrzeżenia budzi zbyt krótki, pięciodniowy termin, a przede wszystkim to, że osoby, które nielegalnie przekroczyły granicę, nie mają możliwości zgłoszenia się do tego urzędu czy posterunku policji, który znajduje się najbliżej miejsca ich aktualnego pobytu. W praktyce oznacza to konieczność powrotu na granicę państwa, w miejsce, w którym dana osoba ją przekroczyła. Biorąc pod uwagę terytorialną rozległość Turcji, nierzadko jest to niewykonalne. Osoby, które nie dotrzymają tego zobowiązania, mogą być wydalone w trybie natychmiastowym, a ich wniosek o nadanie statusu uchodźcy nie jest w ogóle rozpatrywany (Turkey, 1997). Sprzeciw Wysokiego Komisarza NZ ds. Uchodźców budzi również inny przepis, stanowiący, że „Pozwolenie na pobyt, wydane osobom przybywającym do Turcji w celu przemieszczenia się do państw trzecich, w wypadku nieopuszczenia jej terytorium w stosownym czasie, może zostać nieprzedłużone" (Türkiye'ye İltica Eden, 1994: art. 28). Zastosowane tu określenie 'w stosownym czasie', w którym osoba starająca się o status uchodźcy musi opuścić Turcję, jest daleko nieprecyzyjne i powoduje sytuacje, w których status ten zostaje przyznany, nie udaje się jednak znaleźć państwa zdolnego przyjąc uchodźcę, w związku z czym ten jest zawracany na terytoria państwa, z którego przybył.

\section{PRAKTYKA STOSOWANIA ISTNIEJĄCYCH ROZWIĄZAŃ W TURCJI NA POCZĄTKU XXI WIEKU}

Skuteczność funkcjonowania rozwiązań istniejących na gruncie wewnątrzkrajowego porządku prawnego oceniana jest różnie, o ile bowiem są one krytykowane przez UNHCR, Amnesty International czy Unię Europejska, o tyle turecka ich ocena kształtuje się zupełnie inaczej. Jak podkreśla zastępca komendanta Wydziału ds. $O b$ cokrajowców Komendy Głównej Policji Halit Turgut Yıldız, gościnnie uczestniczący w posiedzeniu Podkomisji ds. Uchodźców Parlamentarnej Komisji Praw Człowieka z 26 listopada 2008 r., poświęconego problemowi uchodźców w Turcji, geograficzne i geopolityczne położenie tego państwa zarówno w momencie podpisywania konwencji, jak i współcześnie, w pełni usprawiedliwia stosowanie kryterium geograficznego w dziedzinie przyznawania statusu uchodźców. Zaznacza on również, że z powodu 
tranzytowego położenia oraz walorów turystycznych, liczba obcokrajowców rokrocznie przekraczających granicę z Turcją rośnie, i w samym roku 2008 wyniosła blisko 30 milionów osób, podczas gdy kilka lat wcześniej było to nie więcej, niż 7-8 milionów. Na dowód tego, że Turcja, mimo nieprzyznawania statusu uchodźców osobom przybywającym z państw pozaeuropejskich, zapewnia poszukującym w niej schronienia właściwą opiekę, Yıldız przytacza dane z 2008 r., według których wartość artykułów spożywczych, odzieży, gotówki i terapii przeznaczonych dla 15 tysięcy uchodźców wyniosła ponad 1 milion 300 tysięcy lir tureckich. Ponadto, argumentem na rzecz utrzymania kryterium geograficznego są liczby przytaczane $\mathrm{w}$ raporcie podsumowującym wspomniane posiedzenie podkomisji: w latach 1995-2008 o przyznanie statusu ,poszukującego schronienia” zwróciło się do władz tureckich 58800 osób z 53 państw, z czego prawie 31 tysięcy było obywatelami Iranu, 22 tysiące Iraku, niecałe 3 tysiące Afganistanu i blisko 2 tysiące Somalii. Status ten przyznany został 28 tysiącom, wnioski 11 tysięcy odrzucono, a około 3 tysięcy swoje podania wycofało. Spośród tych, którym status ów przyznano, prawie 12 tysięcy wyjechało do USA, 5,5 tysiąca do Kanady, drugie tyle do państw skandynawskich i około 4 tysięcy do Australii (Türkiye'de, 2008). W tym samym raporcie stwierdzone zostaje, że wbrew częstym zarzutom, kierowanym pod adresem władz Turcji przez międzynarodowe organizacje zajmujące się ochroną praw człowieka, podtrzymywane przez nią kryterium geograficzne nie oznacza przyznawania statusu uchodźcy wyłącznie przybyszom zza jej zachodniej granicy. Halit Turgut Yıldız zwraca bowiem uwagę na to, że status ten przyznawany jest również obywatelom Armenii, Azerbejdżanu i Gruzji, położonych wprawdzie za wschodnią granicą Turcji, traktowanych jednak w tym kontekście jak państwa europejskie. Dowodzi ponadto, że Turcja wywiązuje się ze swych międzynarodowych zobowiązań tak samo, jak wszystkie inne państwa: każdy wniosek o nadanie statusu uchodźcy poddawany jest pod rozwagę odpowiednich władz, które maja prawo zadecydować, czy osoba składająca go spełnia warunki otrzymania konwencyjnego statusu uchodźcy. W razie pozytywnego jego rozpatrzenia, status zostaje przyznany. We wszystkich innych przypadkach, osoba wnioskująca może wystąpić o status „poszukującego schronienia". Dla potwierdzenia tych słów, podaje liczbę 43 osób przebywających w Turcji, które w momencie sporządzania raportu posiadały status uchodźcy (ibidem: 35-40).

Zestawienie przytaczanych powyżej liczb wniosków, jakie wpływały na przestrzeni ostatnich lat od obywateli Iranu, Iraku, Afganistanu czy Somalii, z liczbą 43 osób, którym konwencyjny status uchodźcy przyznano, obrazuje skalę dysproporcji pomiędzy pozytywnymi w tej kwestii decyzjami a rzeczywistym zapotrzebowaniem. Innymi słowy, formalna możliwość uznania za uchodźców nie tylko obywateli Grecji, Bułgarii czy państw bałkańskich, ale też Armenii, Azerbejdżanu i Gruzji, w żaden sposób nie rozwiązuje problemu uchodźstwa w Turcji, zdecydowana bowiem większość osób ubiegających się o ten status, nie pochodzi z tych państw. Mimo nacisków społeczności międzynarodowej, w tym przede wszystkim ONZ i organizacji pozarządowych, takich jak Amnesty International, rząd turecki konsekwentnie odmawiał i nadal odmawia odstapienia od stosowania kryterium geograficznego, powołując się na specyfikę geopolitycznego położenia Turcji i wiążących się z nim wzmożonych procesów migracyjnych. Skutku długo nie odnosiła również argumentacja Unii Europejskiej i to, że 
państwa członkowskie, odwołując się w Karcie Praw Podstawowych do Konwencji dotyczącej statusu uchodźców (Karta, 2012), uznały tę ostatnią za część acquis communautaire. Mimo jednak tego, że jako państwo oficjalnie kandydujące do członkostwa, Turcja powinna być zainteresowana dostosowywaniem własnego porządku prawnego do acquis, jej kolejne rządy konsekwentnie odrzucały możliwość rewizji przepisów dotyczących kwestii uchodźstwa. Tym, co spowodowało pewną zmianę tak twardego stanowiska, stał się wybuch wojny domowej w Syrii, której początek dały antyrządowe protesty z marca $2011 \mathrm{r}$.

Nieoczekiwany rozwój wypadków w sąsiadującej z Turcją od południa Syrii stał się impulsem dla próby dokonania rewizji Ustawy o warunkach pobytu i przemieszczania się obcokrajowców po terytorium Turcji z 15 lipca 1950 r. i Rozporzadzenia w sprawie zasad i procedur dotyczacych osób poszukujących w Turcji schronienia, badź ubiegajacych się o prawo pobytu na jej terytorium $w$ celu przemieszczenia się do państwa trzeciego, badź przekraczajacych jej granice $w$ ramach uchodźstwa zbiorowego, $i$ innych możliwych ruchów ludności. Charakter przebiegu wydarzeń zwanych zbiorczo Arabską Wiosną w innych, objętych nią państwach, nie pozwalał przewidywać przekształcenia się jej syryjskiej wersji w regularną wojnę domową. Wspierające początkowo prezydenta Baššāra al-'Asada władze Turcji nie przewidziały konieczności przyjęcia na własnym terytorium dziesiątek tysięcy uciekinierów, nad którymi konieczne będzie roztoczenie długotrwałej opieki. Dopiero nasilenie starć Armii Wolnej Syrii z siłami rządowymi, lawinowy wzrost liczby Syryjczyków szukających w Turcji schronienia i pogarszające się równolegle stosunki między dwoma państwami, skłoniły stronę turecką do pochylenia się nad zmianą obowiązującego prawa. Z inicjatywy premiera Recepa Tayyipa Erdoğana rozpoczęto prace nad nową ustawą, mającą zawierać rozwiązania adekwatne do rozmiarów problemu, usatysfakcjonować społeczność międzynarodowa, a Turcji pozwolić na utrzymanie kryterium geograficznego w zakresie stosowania konwencji. W efekcie, 16 stycznia 2012 r. premier Turcji przekazał marszałkowi Tureckiego Wielkiego Zgromadzenia Narodowego projekt Ustawy o cudzoziemcach i ochronie międzynarodowej. W poprzedzającym projekt komentarzu, wśród powodów dla których przyjęcie nowych w tej materii regulacji jest konieczne, wymieniono zmieniający się charakter migracji do Turcji. $Z$ państwa tranzytowego staje się ona bowiem państwem docelowym imigrantów, którzy w coraz większej liczbie nie podejmują w ogóle próby przedostania się na zachód, tak jak odbywało się to na przestrzeni dziesięcioleci. Zjawisko to, według autorów komentarza do projektu, wynika z szybkiego, stabilnego wzrostu gospodarczego w Turcji, który w połączeniu z silnie rozwiniętym sektorem przemysłowym i turystycznym, czyni ją coraz atrakcyjniejszym rynkiem pracy. Dla zilustrowania skali zjawiska napływu imigrantów przytoczone zostają następujące dane liczbowe: podczas, gdy w 1995 r. liczba obywateli innych państw, którzy przekroczyli granicę turecka, wyniosła nieco ponad $6 \mathrm{mln} 700$ tysięcy, w roku 2010 było to ponad $27 \mathrm{mln}$; o ile w 1995 r. o pozwolenie na pobyt (a więc przebywanie na terytorium Turcji dłużej niż 30 dni) wystąpiło 85 tysięcy osób, o tyle 15 lat później było ich dwukrotnie więcej. W roku $1995 \mathrm{z}$ wnioskiem o ochronę międzynarodową zwróciło się do władz tureckich niewiele ponad 2 tysiące osób, która to liczba w ciagu kolejnych 15 lat wzrosła dokładnie czterokrotnie - w samym roku 2010 było to ponad 8 tysięcy osób. Łączna liczba próśb o ochronę międzynarodową na przestrzeni 
tego piętnastolecia wyniosła 77430 tysięcy, z czego sprawy ponad jednej trzeciej z nich w momencie kierowania projektu do laski marszałkowskiej wciąż nie były zakończone. Łączna liczba nielegalnych uchodźców zatrzymanych w tym samym okresie na terytorium Turcji bądź w momencie próby przekroczenia jej granic wyniosła ponad 820 tysięcy osób. Odrębnym problemem, który został w komentarzu zasygnalizowany, jest kwestia przemytników uchodźców i handlu ludźmi. W ciągu dwunastu lat, pomiędzy rokiem 1998 a 2010 zatrzymanych zostało prawie 11,5 tysiąca osób trudniących się nielegalnym przeprowadzaniem przez granicę uciekinierów z państw regionu. $Z$ kolei na przestrzeni lat 2005-2010 ,z rąk handlarzy żywym towarem przechwyconych zostało 930 ofiar handlu ludźmi, które następnie w bezpieczny sposób odesłane zostały do państw, z których przybyły" (Yabancllar, 2012). To użyte w komentarzu do projektu omawianej ustawy określenie sugerować ma niezwykle sprawne działanie tureckich służb granicznych, które dzięki szybkiej interwencji uchroniły prawie 1000 osób przed losem nielegalnego imigranta, faktycznie nie wiadomo jednak, na ile osoby te rzeczywiście były ofiarami handlarzy ludźmi, a na ile zdesperowanymi uciekinierami, którzy zapłacili przemytnikom za pomoc w dotarciu do Turcji. Jak wspomniano powyżej, według informacji Amnesty International, nielegalne deportacje do Iranu czy Iraku, bez względu na grożące tam uciekinierom niebezpieczeństwo, wciąż mają miejsce.

W omawianym komentarzu podkreślone również zostaje to, że przedkładany projekt ustawy jest równocześnie przejawem wywiązywania się Turcji z jej zobowiązań, wynikających $\mathrm{z}$ uczestnictwa $\mathrm{w}$ procesie akcesyjnym do UE. Zgodnie z przyjętym w 2003 r. Narodowym Programem Przygotowań do Członkostwa w Unii Europejskiej (ang. National Programme for the Adoption of Acquis; tur. Avrupa Birliği Müktesebatının Üstlenilmesine Illişkin Türkiye Ulusal Programi), jest ona zobowiązana do zrealizowania zapisów przygotowanego na jego podstawie Narodowego Planu Dziatań w sprawie Uchodźstwa i Migracji, który zapewni ujednolicenie tureckiej i unijnej polityki $\mathrm{w}$ tej materii. Wypełnienie Planu jest warunkiem sine qua non otwarcia 24. rozdziału negocjacyjnego pod tytułem „Sprawiedliwość, Wolność, Bezpieczeństwo", obejmującego materię uważaną za jedną z najtrudniejszych w dwustronnych stosunkach Turcja-UE. Jak zostaje podkreślone, w momencie akcesji, Turcja będzie musiała spełniać wszystkie kryteria członkostwa, a kwestia uchodźstwa jest od dawna jedną z bardziej newralgicznych. Rozwiązaniu istniejących na tym polu problemów ma służyć właśnie Ustawa o cudzoziemcach i ochronie międzynarodowej.

Najważniejszą w kontekście międzynarodowych standardów ochrony praw człowieka zmiana, jaka ma na jej podstawie zostać dokonana, jest wprowadzenie zasady non-refoulement $\mathrm{w}$ jej konwencyjnym brzmieniu, wraz z zastrzeżeniem, że z prawa tego nie będzie mogła skorzystać osoba stanowiąca zagrożenie dla bezpieczeństwa państwa (art. 4). Biorąc pod uwagę fakt, iż obecnie obowiązująca ustawa w żaden sposób nie odnosi się do problemu uciekinierów z państw, w których ich życiu lub wolności grozi niebezpieczeństwo, wprowadzenie tego zapisu wydaje się być istotnym krokiem na drodze ku dostosowywaniu tureckiego prawa do wymogów konwencji. Jednocześnie, powtórzony zostaje zapis, zgodnie z którym status uchodźcy przyznawany będzie osobom przybywającym z państw europejskich, przybyszom zaś z poza Europy nadany będzie mógł być status „warunkowego uchodźcy” (tur. şartlı mülteci). Osoby te bedą uprawnione do pozostania na terytorium Turcji do momentu osiedlenia się w państwie 
trzecim, które zdecyduje się na udzielenie im azylu. Tym zaś, które nie będą się kwalifikowały do otrzymania żadnego z nich, a którym w razie powrotu do państwa stałego zamieszkania grozić będzie kara śmierci, tortury, nieludzkie lub niegodne traktowanie, bądź niebezpieczeństwo związane z trwającym konfliktem wewnętrznym lub międzynarodowym, będzie mogła być przyznana ochrona subsydiarna (tur. ikincil koruma) (Yabancılar, 2012). Stworzone zostaną więc dwie zupełnie nowe instytucje prawne, zniknie natomiast kategoria „poszukującego schronienia” (tur. siğınmact), która na gruncie prawa międzynarodowego nie istnieje, co powoduje, że osoby do niej zaliczone znajdują się w swego rodzaju próżni prawnej. Novum jest również wprowadzenie terminu 30 dni od momentu złożenia wniosku o nadanie odpowiedniego statusu, w ciągu których musi odbyć się spotkanie właściwych władz z wnioskodawca, po to, by sytuacja prawna tego ostatniego jak najkrócej mogła pozostawać niejasna (art. 75). Ponadto, procedura rozpatrywania wniosku zakończy się w ciagu 6 miesięcy od jego zarejestrowania nadaniem wnioskodawcy odpowiedniego statusu. Jednocześnie, podkreślone zostaje, że każda sprawa ma charakter indywidualny i w ten sposób będzie rozpatrywana (art. 78). Każdy wnioskodawca, którego sprawa zakończy się nadaniem odpowiedniego statusu, otrzyma potwierdzający go tymczasowy dowód tożsamości, a także dokument podróży. O ile jednak w przypadku osób, którym przyznano status uchodźcy, będą to dokumenty podróży, zgodnie z artykułem 28 konwencji pozwalające im na swobodne podróżowanie, o tyle w przypadku „warunkowych uchodźców” i osób objętych ochroną subsydiarną, będą to jednorazowe dokumenty podróży, wystawiane zgodnie z przepisami Ustawy o dokumentach paszportowych ${ }^{5}$.

Istotnym postępem, w stosunku do obecnie obowiązującego prawa, jest fakt, iż omawiany projekt przyznaje osobom podlegającym międzynarodowej ochronie (a więc zarówno uchodźcom, jak i „warunkowym uchodźcom” oraz osobom korzystającym z ochrony subsydiarnej) szereg praw socjalnych. Zgodnie z proponowanymi zapisami, w zakresie ochrony praw tych osób, wyłączona zostaje zasada wzajemności, co w praktyce oznacza, iż Turcja będzie je respektowała również w stosunku do przybyszów z państw, które podobnych praw nie zapewniają. Jednocześnie, wprowadzone zostaje zastrzeżenie, zgodnie z którym żaden z zapisów przedmiotowej ustawy nie może powodować, że osobom takim będzie przysługiwało więcej praw niż obywatelom Turcji (art. 88). Osoby objęte którąs z trzech form ochrony międzynarodowej oraz ich rodziny będą mogły korzystać ze szkolnictwa na poziomie podstawowym i średnim (art. 89), będą uprawnione do otrzymywania świadczeń w ramach pomocy społecznej państwa (art. 90), dostępne będą dla nich także świadczenia z zakresu ubezpieczeń społecznych, w tym publicznej służby zdrowia (art. 91). Przedstawiciele każdej z tych grup będą również uprawnieni do wykonywania pracy, będzie to jednak łatwiejsze w przypadku osób posiadających status uchodźcy oraz objętych ochroną subsydiarną. W przypadku 'warunkowych uchodźców' i osób, których wniosek nie został jeszcze rozpatrzony, sta-

5 Przewidywane są dwa rodzaje tymczasowych dokumentów paszportowych: wystawiane w celu jednorazowego opuszczenia terytorium Turcji bądź wjechania na nie, co musi nastapić w ciagu 1 miesiąca od momentu wystawienia dokumentu, oraz dokumenty umożliwiające zarówno wjazd i wyjazd, przy czym, jeśli mają być ważne dłużej nić 3 miesiące, decyzję o ich wydaniu podejmuje minister spraw wewnętrznych. Patrz: Pasaport Kanunu (1950), No. 5682. 
ranie się o pozwolenie na pracę będzie możliwe dopiero po upływie 6 miesięcy od momentu jego złożenia (art. 92-93). Ponadto, wszystkim tym osobom, które padły ofiarą tortur, przemocy fizycznej, psychicznej i seksualnej zapewniona zostanie odpowiednia terapia (art. 67); państwo zobowiązuje się również do zapewnienia pomocy tłumacza w zakresie procedur związanych z wypełnieniem i rejestracją wniosku o międzynarodową ochronę oraz podczas spotkania z przedstawicielem władz, w trakcie którego zapaść ma decyzja dotycząca dalszych losów wnioskodawcy (art. 70).

Projekt szeroko odnosi się również do sytuacji apatrydów, którym wydawane mają być odpowiednie dokumenty tożsamości, gwarantujące zakaz ich wydalenia poza terytorium Turcji tak długo, jak długo nie będą stanowili istotnego zagrożenia dla porządku publicznego. Ponadto, osoba nieposiadająca żadnego obywatelstwa, ale mająca taki dokument, w zakresie przepisów o dokumentach podróży oraz o warunkach zatrudnienia, będzie podlegała tym samym przepisom, co inni obcokrajowcy (art. 51). Uwagę zwraca również szeroki katalog osób, które, mimo że nie posiadają statusu formalnie uprawniającego do pozostania na terytorium Turcji, nie będą mogły być deportowane. Prócz objętych zasadą non-refoulement, będą to również osoby niezdolne do odbycia podróży z powodu poważnego stanu zdrowia, ciąży lub wieku, ponadto takie, które poddawane są terapii ratującej życie, której nie mogłyby kontynuować po opuszczeniu Turcji, korzystające z terapii ofiary handlu ludźmi oraz ofiary przemocy fizycznej, psychicznej lub seksualnej, do momentu zakończenia terapii (art. 55). Przewiduje się również powstanie zupełnie nowej instytucji ,ochrony przejściowej” (tur. geçici koru$m a$ ), która przyznana będzie mogła być osobie zmuszonej do opuszczenia własnego państwa i niemogącej do niego powrócić, przy czym szczegóły tej możliwości mają zostać uregulowane mocą rozporządzenia (art. 96). Instytucją odpowiedzialną za realizację i egzekwowanie zapisów ustawy będzie powołana na jej mocy Generalna Dyrekcja do spraw Migracji (tur. Göç İdaresi Genel Müdürlüğ̈̈), wzmocniona zostanie również turecka służba zagraniczna - utworzone zostaną dodatkowe stanowiska konsularne i stanowiska w randze attaché, a osoby je zajmujące odpowiedzialne będą za współpracę z organami państw przyjmujących, odpowiedzialnych za kwestie migracji, oraz podejmowanie działań na rzecz zapobiegania handlowi ludźmi i pomoc ofiarom tego procederu (art. 115) ${ }^{6}$. Według zapowiedzi premiera Recepa Tayyipa Erdoğana, pełna realizacja projektu nastąpi w 2018 r. (Hürriyet, 2012).

\section{PRÓBA OCENY PROPOZYCJI REFORMY POLITYKI MIGRACYJNEJ TURCJI}

Jak starano się wykazać w powyższym przeglądzie propozycji zawartych w projekcie Ustawy o cudzoziemcach i ochronie międzynarodowej, nowe przepisy mają na tle obecnie obowiązującego prawa charakter niemal rewolucyjny. Jednocześnie, niektóre zapisy projektu z różnych przyczyn budzą wątpliwości, wśród których szczególnie

${ }^{6}$ Wszystkie przytoczone powyżej przepisy dotyczące statusu uchodźcy, warunkowego uchodźcy, osób objętych ochroną uzupełniającą bądź przejściową oraz przysługujących im praw pochodzą z projektu ustawy Yabancılar ve Uluslararası Koruma Kanun Tasarlsı. 
istotne wydają się być te związane z treścią artykułu 16. Dotyczy on sytuacji, w których anulowana może być wystawiona już wiza, a wśród powodów dla których może to nastapić, ustawodawca wymienia ,istotne podejrzenie, że obcokrajowiec może popełnić przestępstwo" (Yabanclar, 2012: art. 16). Sformułowanie to pozwala na unieważnienie wizy i tym samym zmuszenie do natychmiastowego opuszczenia terytorium Turcji osoby, co do której można przypuszczać, iż w przyszłości może stać się sprawcą przestępstwa. Nie jest jednak sprecyzowane to, co oznacza określenie ,istotne podejrzenie”, jakie są kryteria owej ,istotności”, kto miałby je formułować, ani to, o jakim przestępstwie jest mowa. Innymi słowy, przepis zawarty w omawianym artykule pozwala na bardzo dowolną interpretację zagrożenia, jakie obcokrajowiec może stanowić, co z kolei powoduje, że w oparciu o ów zapis zmuszony do wyjazdu z Turcji może być właściwie każdy, ponieważ „istotne podejrzenie o popełnieniu w przyszłości przestępstwa" może być skierowane wobec każdej osoby, której obecność na jej terytorium jest z różnych powodów niepożądana. Podobne wątpliwości budzi zapis artykułu 54, dotyczącego okoliczności wydalenia poza granice terytorium Turcji. Jedną z takich okoliczności jest „kierowanie, przynależność, wspieranie organizacji terrorystycznej lub kierowanie, przynależność lub wspieranie innej organizacji o charakterze przestępczym" (ibidem: art. 54). Podobnie, jak w przypadku poprzedniego omawianego zapisu, tak i tutaj pojawia się możliwość bardzo szerokiej interpretacji pojęć zawartych w tym zapisie, a zwłaszcza pojęcia 'wspieranie'. Nie istnieje bowiem zamknięty katalog czynności czy działań, które są za ‘wspieranie' uznawane, co oznacza, że bardzo łatwo jest o nie posądzić i dokonać w oparciu o to deportacji. Dodatkowo, uwagę zwraca brak zapisu o konieczności istnienia orzeczenia sądu w tej sprawie, co stoi w sprzeczności z kodeksem karnym. Ten bowiem stanowi, że „Każdy obcokrajowiec, który został skazany na karę pozbawienia wolności dłuższą niż okres dwóch lat, zostaje jednocześnie skazany na opuszczenie terytorium Turcji niezwłocznie po odbyciu kary" (Türk, 2004: art. 59). Innymi słowy, warunkiem legalności deportacji jest decyzja właściwego sądu, czego projekt Ustawy o cudzoziemcach i ochronie międzynarodowej nie przewiduje. To zaś powoduje sytuację, w której samo podejrzenie o przynależność lub wspieranie organizacji terrorystycznej lub innej przestępczej, stanowi podstawę do wydalenia poza granice państwa. Taki zapis, typowy dla tureckiego prawodawstwa, wynika $\mathrm{z}$ faktu, iż Turcja jest państwem, które od przeszło trzydziestu lat prowadzi walkę z terrorystyczną Partia Pracujacych Kurdystanu (PKK), długo walczącą o utworzenie na terenach południowo-wschodniej Anatolii niepodległego państwa kurdyjskiego, dziś mówiącą o innej formie autonomii i z nadzieją przyglądającą się syryjskiej wojnie domowej, która stanowi bezprecedensową szansę na emancypację polityczną Kurdów syryjskich, co byłoby bardzo niekorzystne dla Turcji i bardzo po myśli PKK. Jest więc uzasadnione, dlaczego kwestie przynależności do organizacji terrorystycznej budzą u tureckich władz tak duże emocje, nie usprawiedliwia to jednak możliwości deportacji bez orzeczenia sądu, ani tym bardziej dowolności w uznawaniu za członka bądź sprzymierzeńca organizacji o charakterze terrorystycznym.

Kolejne wątpliwości budzi zapis, zgodnie z którym „Osobie, wobec której podjęto decyzję o deportacji, przysługuje nie mniej niż 7 i nie więcej niż 30 dni na opuszczenie terytorium Turcji. Okres ten nie będzie obowiązywał jednak w przypadku osób, co do których istnieje podejrzenie ucieczki, [...], bądź tego, że stanowić będą zagrożenie dla 
porząqku publicznego" (Yabancllar, 2012: art. 56). Przepis ten stanowić będzie realne pole do nadużyć, zezwala bowiem na wydalenie osoby objętej nakazem deportacji w czasie niepozwalającym na dokonanie najbardziej odstawowych czynności, w tym zabranie ze sobą znajdujących się na terytorium Turcji rzeczy osobistych i ruchomości. Uwagę zwraca również treść artykułu 82, stanowiącego, że na osoby, którym nadano status „uchodźcy warunkowego" lub przyznano ochronę subsydiarna, z powodów związanych z koniecznością zapewnienia porządku publicznego, może zostać nałożony obowiązek każdorazowego informowania odpowiednich władz o miejscu zamieszkania, aktualnego pobytu i każdej zmianie, jaka w tych kwestiach nastąpi. Jednocześnie, projekt nie stwarza możliwości nałożenia tych obowiązków na osoby o statusie uchodźcy, co stanowi bardzo wyraźny rozdźwięk pomiędzy ich sytuacją a położeniem osób objętych pozostałymi formami ochrony międzynarodowej.

Zastrzeżenia do omawianego projektu wynikają jednak nie tylko z zapisów, które się w nim pojawiły, ale także $\mathrm{z}$ braku pewnych sformułowań, które $\mathrm{w}$ akcie prawnym o tak dużym znaczeniu pojawić się powinny. Jak zwraca uwagę turecka Organizacja Wspótpracy na rzecz Prześladowanych i Przestrzegania Praw Człowieka (tur. Insan Hakları ve Malzumlar için Dayanışma Derneği - MALZUMDER), najbardziej istotnym zapisem, który pierwotnie znalazł się w projekcie, szybko jednak został z niego wycofany, jest zapis o zakazie jakiejkolwiek dyskryminacji. W opinii jej przedstawicieli, wprowadzenie do projektu takiego zakazu, mającego umocowanie w artykule 14 europejskiej Konwencji o Ochronie Praw Człowieka i Podstawowych Wolności oraz artykule 10 Konstytucji Republiki Turcji, podniosłoby rangę przygotowywanej ustawy i jednoznacznie gwarantowało jego stosowanie również wobec osób korzystających z ochrony międzynarodowej. Podobne wątpliwości organizacji MALZUMDER budzi treści artykułu 65, stanowiącego, że osoba starająca się o międzynarodową ochronę, składa wniosek o jej przyznanie osobiście. Według jej przedstawicieli, prawo do jego złożenia powinien mieć również adwokat lub inny pełnomocnik prawny. Z krytyką spotyka się również brak zapisu o tym, że wszelkie decyzje związane z wnioskiem powinny być przedstawiane jego autorowi w zrozumiałym dla niego języku. W zamian za to, w artykule 70. projektu pojawił się zapis gwarantujący wsparcie tłumacza, jak jednak zauważa przedstawiciel organizacji, brak tu sformułowania o jego bezpłatności, co rodzi kolejne pole do nadużyć ze strony urzędników (Foça, 2012).

$* * *$

Jak starano się wykazać w powyższej analizie, znajdujący się już w tureckim parlamencie projekt Ustawy o cudzoziemcach i ochronie międzynarodowej, stanowi bardzo istotny krok w stronę ujednolicania tureckiej polityki azylowej i prawnomiędzynarodowych oraz europejskich standardów w tej dziedzinie. Wskazane wątpliwości dowodzą niedoskonałości zaproponowanych rozwiązań i w uzasadniony sposób budzą zastrzeżenia organizacji zajmujących się ochroną praw człowieka, nie zmienia to jednak faktu, że samo pojawienie się takiego projektu świadczy o istotnej zmianie, jaka dokonała się w myśleniu tureckich przywódców politycznych. Konsekwentnie na przestrzeni lat odmawiająca zrewidowania swojej polityki azylowej Turcja, znacznego postępu dokonała przyznając w ogóle, iż problem przybyszów spoza państw europejskich istnieje 
i musi zostać rozwiązany. Nie doszło by jednak do tego prawdopodobnie, gdyby nie wydarzenia w Syrii, które w ciągu kilku zaledwie miesięcy przekształciły się w wojnę domową, wśród której konsekwencji problem uchodźców wysuwa się na pierwszy plan. Zgodnie z obecnie obowiązującym prawem, przybywający do Turcji Syryjczycy znajdują się w swoistej próżni prawnej, nie ma bowiem możliwości nadania im statusu uchodźcy i z punktu widzenia prawa traktowani są jak wszyscy inni obcokrajowcy. W praktyce oznacza to, że ponad 100 tysięcy osób, zgromadzonych w czternastu obozach na granicy turecko-syryjskiej nie ma prawa do opieki lekarskiej, świadczeń z zakresu pomocy społecznej czy edukacji w instytucjach publicznych. Wsparcie, jakie obecnie otrzymuja, ma bowiem charakter pomocy humanitarnej, a nie systemowej, zapewnianej uchodźcom przez państwa-strony Konwencji dotyczącej statusu uchodźców. Sytuacji ich nie zmienia również działalność tureckiego przedstawicielstwa Wysokiego Komisarza NZ do spraw Uchodźców, którego rolą jest pomoc w znajdowaniu azylu, ponieważ jednak strona turecka odmawia przyznawania statusu uchodźcy przybyszom z Syrii, Iranu, Iraku, Afganistanu czy Somalii, nie ma możliwości przesiedlenia ich do państw trzecich. Co więcej, również sytuacja osób, które otrzymały status uchodźcy, głównie obywateli państw południowej Europy oraz Czeczenów, nie jest idealna, jak bowiem informuje Amnesty International, mają miejsce sytuacje, w których tureckie władze odmawiają przyznania tego statusu osobie uznanej za uchodźcę przez tureckie przedstawicielstwo UNHCR. Co więcej, AI podkreśla problemy w dostępie do procedur azylowych, w tym głównie brak punktów, w których wniosek mógłby być złożony, brak możliwości kontaktu z prawnikami i przedstawicielami organizacji pozarządowych (Amnesty International, 2009).

$\mathrm{Na}$ tym tle, krok, jakim jest skierowanie pod obrady parlamentu omawianego projektu ustawy, nie powinien być niedoceniany, stanowi on bowiem rewolucyjną zmianę w tureckiej polityce, a jego realizacja znacznie przybliży Turcję do międzynarodowych standardów ochrony praw człowieka. Jednocześnie, nie zostaną spełnione oczekiwania unijnych przywódców, kierujących pod adresem jej władz żądania zniesienia kryterium geograficznego w stosowaniu konwencji, a projekt ustawy ma być swego rodzaju 'złotym środkiem', stanowiącym wypadkową pomiędzy interesami Turcji a wymogami ochrony praw osób uciekających z państw, w których ich życie lub bezpieczeństwo jest zagrożone. $Z$ tego powodu, jakkolwiek proponowane rozwiązania nie są idealne, w opinii autorki należy je uznać za przejaw pozytywnych zmian w tureckiej polityce wobec uchodźców.

\section{Bibliografia}

Afet ve Acil Durumu Yönetimi Başkanlığı, strona internetowa tureckiego Departamentu Zarządzania Kryzysowego, https://www.afad.gov.tr/TR/HaberDetay.aspx?IcerikID=2713\&ID=5, 23.02.2014.

Esad ve Erdoğan aşkı sürecek mi? (2011), „Vatan”.

Foça M. A., Göç politikası değişiyor, tasarısı komisyonda, strona internetowa tureckiego portalu informacyjnego Bianet, http://www.bianet.org/bianet/bianet/138572-goc-politikasi-degisiyor-tasari-komisyonda, 19.12.2012. 
Haydi AB göreve (2012), „Die Welt”.

İçişleri Bakanlı̆̆g 'ndan iki dev yapılanma (2012), „Hürriyet”.

Karta Praw Podstawowych Unii Europejskiej (2012), Dz. U. UE, 30.03.2012, C 83/389.

Konwencja dotyczqca statusu uchodźców (1951), Dz. U. 1991, Nr 119, poz. 515.

Konwencja wiedeńska o prawie traktatów (1969), Dz. U. 1990, Nr 74, poz. 439.

Opuszczeni - uchodźcy w Turcji pozbawieni ochrony (2009), Amnesty International, http://amnesty.org.pl/uploads/media/Streszczenie_raportu.pdf, 15.12.2012.

Pasaport Kanunu No 5682 (1950), „Resmî Gazete”, 24.07.1950.

Protokót dotyczqcy statusu uchodźców (1967), Dz. U. 1991, Nr 119, poz. 517.

State Parties to the 1951 Convention relating to the status of refugees and the 1967 Protocol, http://www.unhcr.org/3b73b0d63.html, 13.12.2012.

Turkey - the refoulement of non-European refugees-a protection crisis (1997), Amnesty International, http://www.amnesty.org/es/library/asset/EUR44/031/1997/es/30c9c009-ea7e-11dd-b05d-65164b228191/eur440311997en.pdf, 15.12.2012.

Türk Ceza Kanunu No 5237 (2004), „Resmî Gazete”, 12.10.2004.

Türkiye 'ye İltica Eden veya Başka Bir Ülkeye İltica Etmek Üzere Türkiye'den İkamet İzni Talep Eden Münferit Yabancllar ile Topluca Siğınma Amacıyla Sinırlarımıza Gelen Yabancılara ve Olabilecek Nüfus Hareketlerine Uygulanacak Usul ve Esaslar Hakkında Yönetmelik No 359 (1994), „Resmî Gazete”, 30.11.1994.

Türkiye'de bulunan mülteciler, sı̆̆ınmacılar ve yasa dışı göçmenlerin sorunları inceleme raporu, strona TBMM, Tureckiego Wielkiego Zgromadzenia Narodowego, http://www.tbmm.gov.tr/ komisyon/insanhaklari/belge/gocmen_raporu.pdf, 15.122012.

Yabanclların Türkiye'de ikamet ve seyahatleri hakkında kanun No 5683 (1950), „Resmî Gazete”, 24.07.1950.

Yabancılar ve Uluslararası Koruma Kanun Tasarısı, strona TBMM, Tureckiego Wielkiego Zgromadzenia Narodowego, http://www2.tbmm.gov.tr/d24/1/1-0619.pdf, 16.12.2012.

\section{STRESZCZENIE}

Celem publikacji jest podjęcie próby przeanalizowania polityki, jaką Turcja prowadzi wobec obcokrajowców poszukujących schronienia na jej terytorium. O ważkości zagadnienia zadecydowała w ostatnich latach przede wszystkim tocząca się w Syrii wojna domowa, w wyniku której na terytorium Turcji znalazło się ponad 700 tysięcy Syryjczyków. Szczególne w tym kontekście kontrowersje budzi fakt stosowania przez Turcję podwójnych standardów w przedmiocie nadawania imigrantom konwencyjnego statusu uchodźcy. Państwo to, jako jedno z czterech na świecie, w momencie przystępowania do Konwencji dotyczącej statusu uchodźców i Protokołu nowojorskiego zastrzegło sobie prawo do stosowania w tej materii tzw. kryterium geograficznego. W efekcie, o ile status uchodźcy nadany być może osobom przybywającym zza zachodnich granic Turcji, o tyle uciekinierzy z państw takich, jak Syria, Iran czy Irak z formalnego punktu widzenia są ,poszukującymi schronienia” (tur. sığınmacl). To zaś oznacza brak ich konwencyjnej ochrony. Celem artykułu jest jednak nie tylko przeanalizowanie prawnego i rzeczywistego położenia, w jakim znajdują się ofiary syryjskiej wojny domowej, przybywające na terytorium Turcji, a także próba przewidzenia scenariusza rozwoju tejże sytuacji. Celem uczynienia analizy możliwie najbardziej rzetelną, odwołano się zarówno do anglo-, jak i tureckojęzycznych materiałów źródłowych. 


\title{
CONVENTION RELATING TO TEH STATUS OF REFUGEES AND TURKISH PRACTICE. THE PROBLEM OF ASYLUM SEEKERS COMING FROM BEYOND THE EASTERN BORDERS OF TURKEY
}

\begin{abstract}
The aim of this article is to take an attempt to analyze Turkish policy towards foreigners looking for a shelter on the territory of Republic of Turkey. Increasing importance of this issue during last few years arises first of all from ongoing civil war in Syria, as a result of which a number of Syrians in this country exceeded 700 thousands. What gives rise to particular controversies in this matter is the fact that Turkish state uses double standards in the issue of granting the refugee status. Turkey, as a one of four countries in the world, when signing the Convention and Protocol relating to the status of refugee, announced an introduction of a so-called geographical limitation. As a result, while the refugee status can be granted only to persons coming to Turkey from beyond it's western borders, those who come from countries like Syria, Iraq or Iran are being called 'asylum seekers' (tur. siğı $\mathrm{imact}$ ). That means that they are not entitled to benefit from a conventional refugee protection system. The objective of this article is not only to present a legal and real situation of victims of the Syrian civil law but also to make an attempt to foresee moves that may be taken in this matter by the Turkish government in the future. In order to make the analysis possibly most comprehensive either English or Turkish language sources were used by the author during preparation of the text.
\end{abstract}


